\title{
Classroom Interactional Competence of English Classes in Higher Education
}

\author{
Soraya $^{1}$ \\ ${ }^{1}$ STBA LIA Jakarta \\ Email: untuk.soraya@gmail.com
}

\begin{abstract}
English Students of higher education are expected to have mastery in the language as well as ability to think critically. However, the characteristic of EFL (English as a Foreign Language) classes shows that teacher tend to dominate the class. Thus, the research aims to discover the classroom interactional competence in ELT classes of higher education in order to achive the expected learning objective. The interaction will be analyzed based on the micro contexts and the pedagogic goals. This research is conducted with qualitative approach and content analysis method. The data source is the recording of 10 English classes at STBA LIA Jakarta. The data are analyzed using L2 classroom modes framework by Steve Walsh. The result shows that lecturers mostly apply material and managerial mode but rarely apply the classroom context and skill and system mode. The most interactional features found are display questions and extended teacher turns. The research concludes that the lecturer focuses on preparing the students background information to express student's critical thinking and fluency but they have not prepared the students' language components and skills to support the fluency. The implication is that the lecturers tend to dominate the interaction, as mentioned by Walsh. However, it is the way to to maintain the communication practice by modifying the interactional features which is appropriate to the learners and facilitating the interactional space so that the interactional competence of the students can be elevated.
\end{abstract}

Keywords: classroom interactional competence; interactional features; higher education; english language teaching

\section{INTRODUCTION}

In higher educational level, generally, lecturers expect critical thinking from the students. According to National Education Standard [1], learning should be cultivated in a democratic atmosphere so that the learners are courageous to deliver ideas. Whitehead [2] stated that "the often articulated aim that university students should develop the ability to "think critically.",

However, the implementation of critical thinking activity is one of the obstacles in foreign language classes because it is a setting with central and complex communication. According to Walsh [7] "One of the most striking features of any classroom is that the roles of the participants (teacher and learners) are not equal. They are asymmetrical one party is in a position of power or authority; that person has control of the patterns of communication that occur and is able to direct and manage the 
interaction." (p. 4). Usually, the lecturers/teachers control the topic of conversation and turn-taking. Moreover, ELT class has features in which (1) teacher and students have to deal with the specific turn taking in the class, but (2) only teacher can select the next speaker, interrupt, and decide the length of the waiting time [4]. Indirectly, in such condition, the lecturer dominates the classroom talk. Even though, there are situations when teachers allow more participation by the students, most of the time, students only respond the cues given in the form of a spoken response, an action, etc.

Thus, there is a gap of students' expected ability with the realization in the learning process. Many lecturers, then, focus to find teaching methods to improve students' ability in English. Nevertheless, the quality of learning achievement is not solely determined by the methods. McCharty and Walsh [5] stated "For language teachers, understanding the discourse of the classroom itself is crucial, for we teach discourse through discourse with our learners." Inside the class, the learning purpose and the use of language can't be separated because all classroom discourse is goal-oriented. In that case, the main responsibility of what is said in the classroom is on the teacher because he/she "orchestrates and controls classroom interaction" [6].

An interactive activity in the class is formed through the decision of the lecturer/teacher because the response given by the students depends on the questions posed by the lecturers. Classroom interaction is the center of the learning process and the most important element in curriculum because learning does not happen through the interaction but in the interaction process [3]. It can be said that interaction is something important in the learning process because classroom interaction is related to the material, syllabus, communication, motivation, identity, theory, and practice.

Interaction process also shapes the learning achievement. The language used by the lecturers as the medium of instruction determines the interaction in the learning process. Kalantari (2009) also said that interaction is centralized to the communicative competence and language which students obtain when they actively interact in the target language. For the students, classroom interaction between the lecturer and the students is the most important access to the language learned [9]. because interaction is the key of ELT. When the students listen to the language, they actually learn English. Hence, interaction consists of two dimensions: the participants and the purpose [11].

Hence, lecturers/teachers and students are the key elements because the lecturers manages various components in the interaction and express it to the students. Without a proper response from the students, the interaction will not flow smoothly. The lecturers can focus to the interaction to adjust the learning and the competence of the participants. Therefore, to ensure the interaction can be well adjusted with the learning process, the lecturers must have English competence which fulfills the standard, either for specific goal (formal or informal communication) or for educational goal [10]. Language competence of a lecturer is not in cognitive level anymore but in real communication level. In that case, the ability to understand classroom discourse dynamics is important in order to maintain the communication practice.

Therefore, lecturers/teachers need to have classroom interactional competence. Classroom interactional competence is defined as teachers' and learners' ability to use interaction as a tool for mediating and assisting learning. Interactional competence manifests itself through (1) the use of language that is both convergent to the pedagogic goal and appropriate to the learners, and (2) facilitating the interactional space [3].

The interaction captures the learning activity happened and it helps the lecturers to make important decisions in the process. The success of a pedagogical activity needs 
successful interaction management. Thus, it's very important for teachers to understand the interaction to achieve certain pedagogic goals. Pedagogic goals determine the action focused in the class. The goals can be realized from the interactional features performed in the class. Therefore, the interaction in the class is usually in accordance to the pedagogic goals because pedagogical goals determine the action focused in the class.

The pedagogical goals are categorized into four microcontexts or modes. The microcontexts are the setting for certain the pedagogic goals. The first is managerial mode which focuses on delivering information and managing the class. Material mode focuses on the learning material. Skills and system mode focuses on teaching language skills, such as reading, writing, speaking, and listening, and language components, such as grammar, vocabulary, and phonology (pronunciation). The last one, classroom context mode provides the students with more opportunity to express themselves in the language learned.

Each mode has several pedagogical goals which are specifically related to the learning activity. For example, to manage the class, the teachers/lecturers need to transmit information, introduce new activity, etc. To express students' mastery of English in classroom context mode, the teachers/lecturers need to promote the students oral fluency. Each pedagogical goal is realized in some interactional features. The framework of Walsh L2 classroom mode can be seen in the following table.

Table I. Framework of Interactional Features in L2 Classroom Modes

\begin{tabular}{|c|c|c|}
\hline Mode & Pedagogic Goals & Interactional features \\
\hline Managerial & $\begin{array}{l}\text { a. To transmit information } \\
\text { b. To organize the physical learning } \\
\text { environment } \\
\text { c. To refer learners to the material } \\
\text { d. To introduce or conclude an } \\
\text { activity } \\
\text { e. To change from one mode of } \\
\text { learning to another }\end{array}$ & $\begin{array}{l}\text { A single extended teacher turn which } \\
\text { uses explanation and/or instruction } \\
\text { The use of transsitional markers the } \\
\text { use of confirmation checks } \\
\text { An absence of learner contribution }\end{array}$ \\
\hline Material & $\begin{array}{l}\text { a. To provide language practice } \\
\text { around a piece of material } \\
\text { b. To elicit responses in relation to } \\
\text { the material } \\
\text { c. To check and display answers } \\
\text { d. To clarify when necessary } \\
\text { e. To evaluate contribution }\end{array}$ & $\begin{array}{l}\text { Predominance of IRF pattern } \\
\text { Extensive use of display question } \\
\text { Form-focused feedback } \\
\text { Corrective repair } \\
\text { Scaffolding }\end{array}$ \\
\hline Skills and system & $\begin{array}{l}\text { a. To enable learners to produce } \\
\text { correct forms } \\
\text { b. To enable learners to manipulate } \\
\text { the target language } \\
\text { c. To provide corrective feedback } \\
\text { d. To provide learners with practice } \\
\text { in sub-skills }\end{array}$ & $\begin{array}{l}\text { The use of direct repair } \\
\text { scaffolding } \\
\text { extended teacher turns } \\
\text { display questions } \\
\text { teacher echo } \\
\text { clarification request } \\
\text { form-focused feedback }\end{array}$ \\
\hline $\begin{array}{l}\text { Classroom } \\
\text { Context }\end{array}$ & $\begin{array}{l}\text { a. To enable learners to express } \\
\text { themselves clearly } \\
\text { b. To establish a context } \\
\text { c. To promote oral fluency }\end{array}$ & $\begin{array}{l}\text { Extended learner turns } \\
\text { Short teacher turn } \\
\text { Minimal repair } \\
\text { Content feedback } \\
\text { Referential question } \\
\text { Scaffolding } \\
\text { Clarification request }\end{array}$ \\
\hline
\end{tabular}




\section{METHOD}

The research design applied in this research is content analysis by using second language classroom mode framework from Steve Walsh [7]. The data are collected by recording the interaction of 10 ELT classes of STBA LIA lecturers. The recording of each class are conducted three times. The transcriptions of the interactions process are analyzed using qualitative method. The research questions are:

1. What are the interactional features applied in each mode?

2. How is the classroom interactional competence of English classes of higher education?

\section{RESULT}

Based on the analysis of classroom interaction in the English classes of STBA LIA Jakarta, there 533 data which are categorized into four modes. The analysis of each mode will reveal the pedagogical and interactional features applied in the classes.

\section{Interactional Features in Managerial Mode}

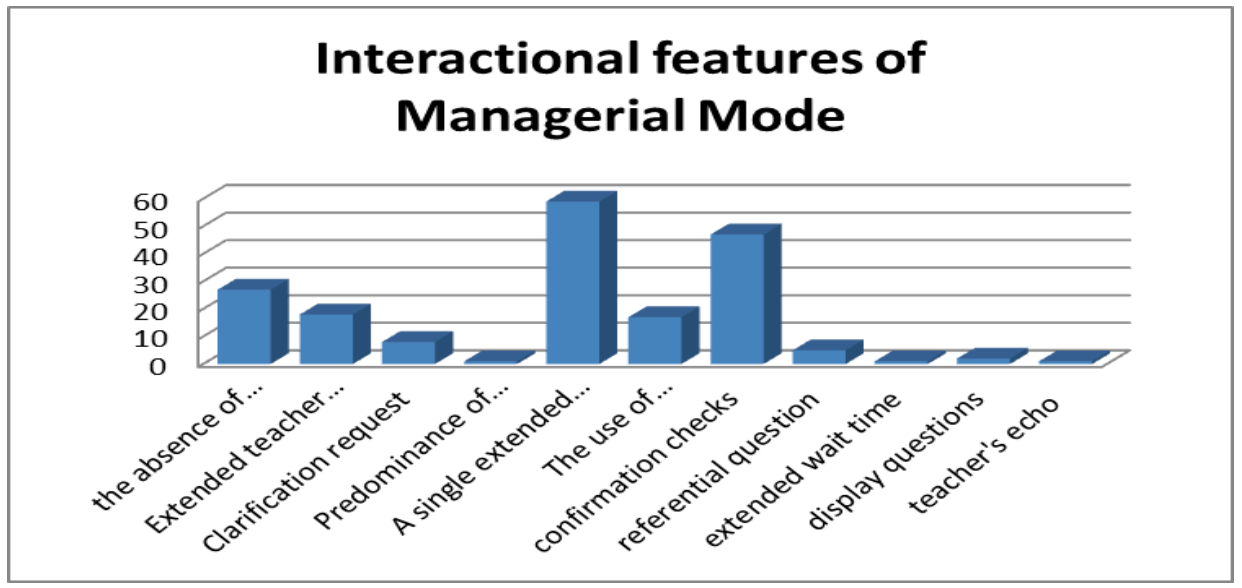

Figure 1. The findings of interactional feature in managerial mode

When managing the class, the interaction, mostly dominated by instruction and explanation of the lecturer in form of a single extended teacher turn that uses explanation and/or instructions, whether it's related to topic discussed or to the classroom activity. The lecturers also tend to introduce new activity in by giving instructions repeatedly. The pedagogical goal of introducing new activity, are mostly characterized by the absence of learner contribution. It shows that, generally, when the lecturer gives instruction, the students listen to the instruction. The information of new activity conducted with extended teacher turn as interactional features in order to clarify the information. Even though, the activity is introducing new activity, the lecturers also use interactional feature which involves the students, such as confirmation checks and clarification request to ensure that the students comprehend the activity. When there are things which students need to do, the lecturers deliver the message using transitional markers to make it easier for the students to grasp the instruction.

To organize physical learning environment, there is only a single extended teacher turn which uses explanation or instruction and the use of confirmation checks. It 
indicates that the lecturers organize the classroom environment by giving instruction and confirming the students' comprehension to ensure that they know what to do. Next, to transmit information, the lecturers also dominate the interactional features with a single extended teacher turn which uses explanation or instruction because they fulfill the role as the source. Another pedagogical goal in managerial mode is to refer students to the material. Mostly the lecturers apply extensive use of display questions, referential questions to check, and the use of confirmation checks. When students give the correct answer, the lecturers will do teacher's echo to ensure that the students remember the answer. To conclude an activity, the lecturers mark the goal by using confirmation checks as the interactional feature. The lecturers ensure students to remember all of the information by applying transitional markers.

\section{Interactional Features in Material Mode}

Material mode is microcontext with pedagogical goals centered to the material. In material mode, there are 292 data for seven pedagogical goals, namely (1) to evaluate contributions, (2) to check and display answer, (3) to clarify when necessary, (4) to elicit responses in relation to the material, and (5) to provide language practice around a piece of material. The interactional features used to achieve the pedagogic goals in material modes are teacher interruptions, content feedback, extended teacher turns, clarification request, display questions, scaffolding, corrective feedback, teacher echo, extended wait time, predominance of IRF pattern, corrective feedback, referential questions, and turn completion.

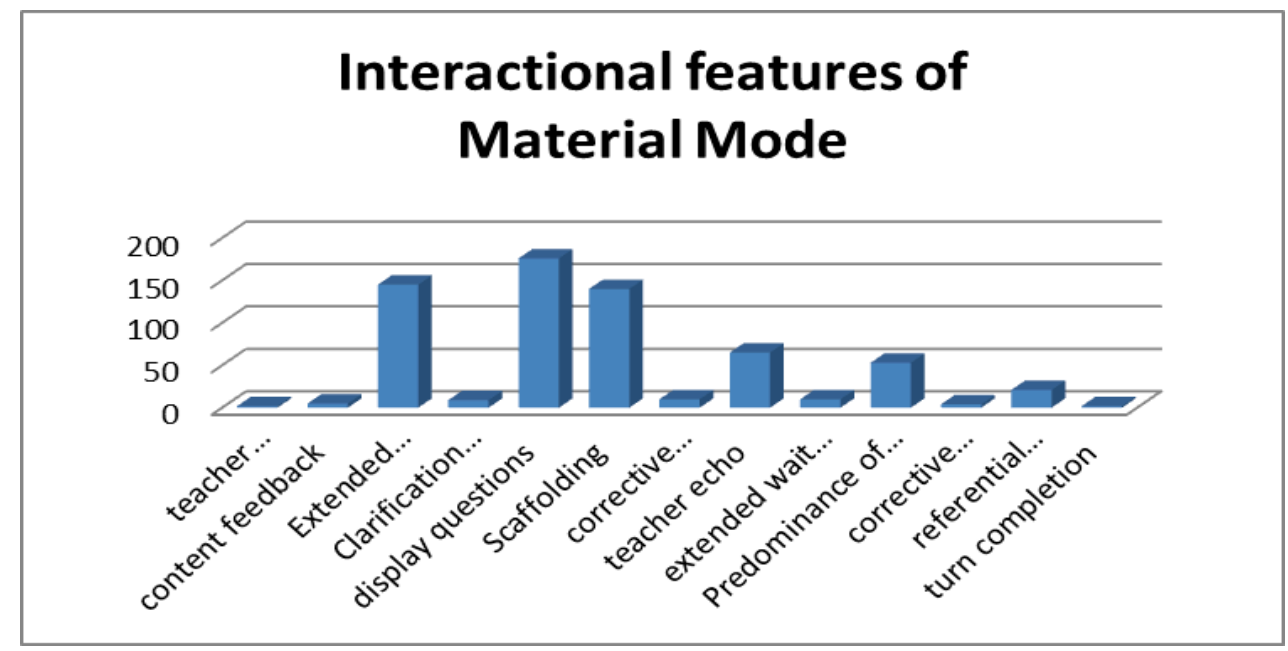

Figure 2. The findings of interactional feature in material mode

Generally, the data show that in material mode, the dominant pedagogical goal is to check and display answer and to to elicit responses in relation to the material. The goals indicate that the lecturers want to have more elicitation related to the material. The lecturers want the students to understand the material discussed. When the students do not give the correct response, the lecturers will rectify it.

The lecturers apply several interactional feature to check and display answer during practice. Practice time is the important moment for students to strengthen their comprehension on the material. Thus, the lecturers evaluate students' contribution. Other pedagogical goals found in material mode are to provide language practice 
around a piece of material, to evaluate contributions, and to clarify when necessary. Language practice is needed because students deliver the material in English. In that case, the lecturer make use of the interactional feature to reinforce students' language competence.

The pedagogical goal of providing language practice around a piece of material is realized by using scaffolding, predominance of IRF pattern, referential questions, and turn completion. Mostly, the language practice is conducted by modifying questions or to lead the interaction so that the students do not realize that the lecturers are actually giving them practice aroud the material.

\section{Interactional Features in Skills and System Mode}

From all modes found in classroom interaction, the skills and system mode is the least found in the data. Mostly, the discussion in the class is topic-based or material based even though it is for skills subjects. The pedagogic goals focused in the mode are (1) to display correct answer, (2) to enable learners to produce correct form, and (3) to provide corrective feedback. The interactional features found are form-focused feedback, clarification request, direct repair, predominance of IRF pattern, scaffolding, extended teacher turns, and teacher's echo.

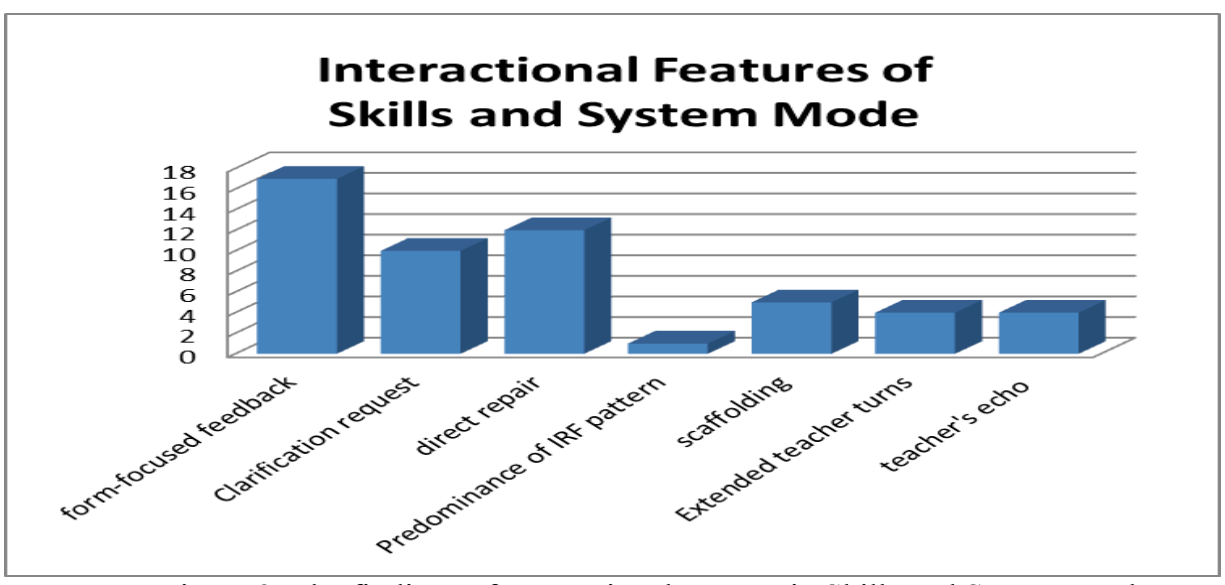

Figure 3. The findings of Interactional Feature in Skills and System Mode

When trying to display the correct answer, the lecturer mostly use form-focused feedback and clarification request as the interactional feature. It shows that when the students make mistake in vocabulary, grammar, or pronunciation, the lecturers do not provide the correct answer directly. They provide form-focused feedback or clarification request so that the answer generated comes from the students themselves.

The pedagogical goal of enabling learners to produce correct form is realized in many interaction forms. It depends on the language component need to be fixed. When the students mispronounce a word, the interactional feature applied is direct repair. However, when the mistake is related to grammar or vocabulary, the lecturers will request for clarification at first. After the mistake being clarified, the lecturers will do scaffolding, predominance of IRF, or extended teacher turn to provide hints so that the students can generate the correct form. Once, it is correct, the lecturers will do teachers' echo so that the students will remember the form. 
To enable learners to produce correct form, the lecturers indirectly provide corrective feedback or the correct answer. It indicates that the lecturers want the students to identify the mistake and fix it. The lecturers expect the students to use their own reasoning based on the learning experience while prolonging the interactional chance in the classroom.

\section{Interactional Features in Classroom Context Mode}

Classroom context mode can be characterized by pedagogical goals to let the students share the experience, feelings, emotion, attitude, etc. In this mode, the lecturers make effort to enable learners (1) to express themselves clearly, (2) to promote oral fluency, and (3) to establish a context. The interactional features applied to achive the pedagogic goals are extended learner turns, content feedback, minimal repair, clarification request, referential questions, short teacher turns, scaffolding, and teacher's echo.

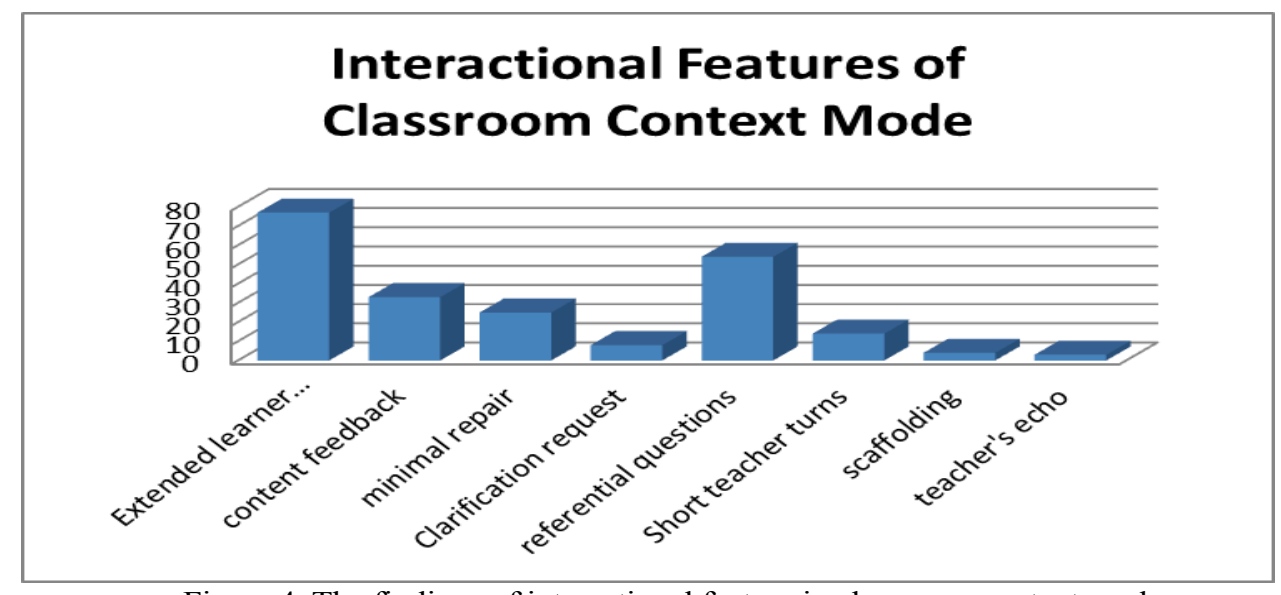

Figure 4. The findings of interactional feature in classroom context mode

In general, in classroom context mode, the lecturers build the context so that the material can be learned easily. Once context is built, they maximize the students interaction by helping them express themselves clearly and promoting oral fluency.

Interactional features dominantly found to enable learners to express themselves clearly is extended learner turns. It makes the students have more opportunity. The lecturers help by giving minimal repair so that the students' fluency is not disturbed.

To promote oral fluency, mostly the lecturers use interactional features such as referential questions and minimal repair. The lecturers also maximize the students turn by seeking clarification about what the students want to express. Hence, the students can still express themselves in English while fixing the problems. To establish a context, the dominant interactional feature is referential question. It is the way the lecturers build a context through meaningful questions (not just answers of language practice). Other interactional features found are extended learner turns, short teacher turn, and content feedback. It shows that the lecturers give more turns to the students in order to stimulate students to interact.

From the interactional features of all microcontexts and pedagogic goals, the features mostly found are extended teacher turn, display questions, scaffolding, referential questions and extended learners turn. It shows that in creating classroom 
interaction, the lecturers mediate and assist the learning by giving more explanation and starts from something that the students know. It means that the lecturers facilitate the learning by giving more explanation or involving other students so that the interaction can keep on going. Once the interaction is set, the lecturers increase students ability to interact by using scaffolding, posing referential questions, and extending learners' turn. Sometimes, the students encounter the difficulty of expressing the thought, not because they do not know the answer. They need assistance to channel the thoughts in the language. Therefore, scaffolding and extended learner turn can maximize the contribution in the interaction. Referential questions can be the trigger to enable learners to talk more because referential questions posed are usually related to their lives. It also has the impact to facilitate the students interactional space.

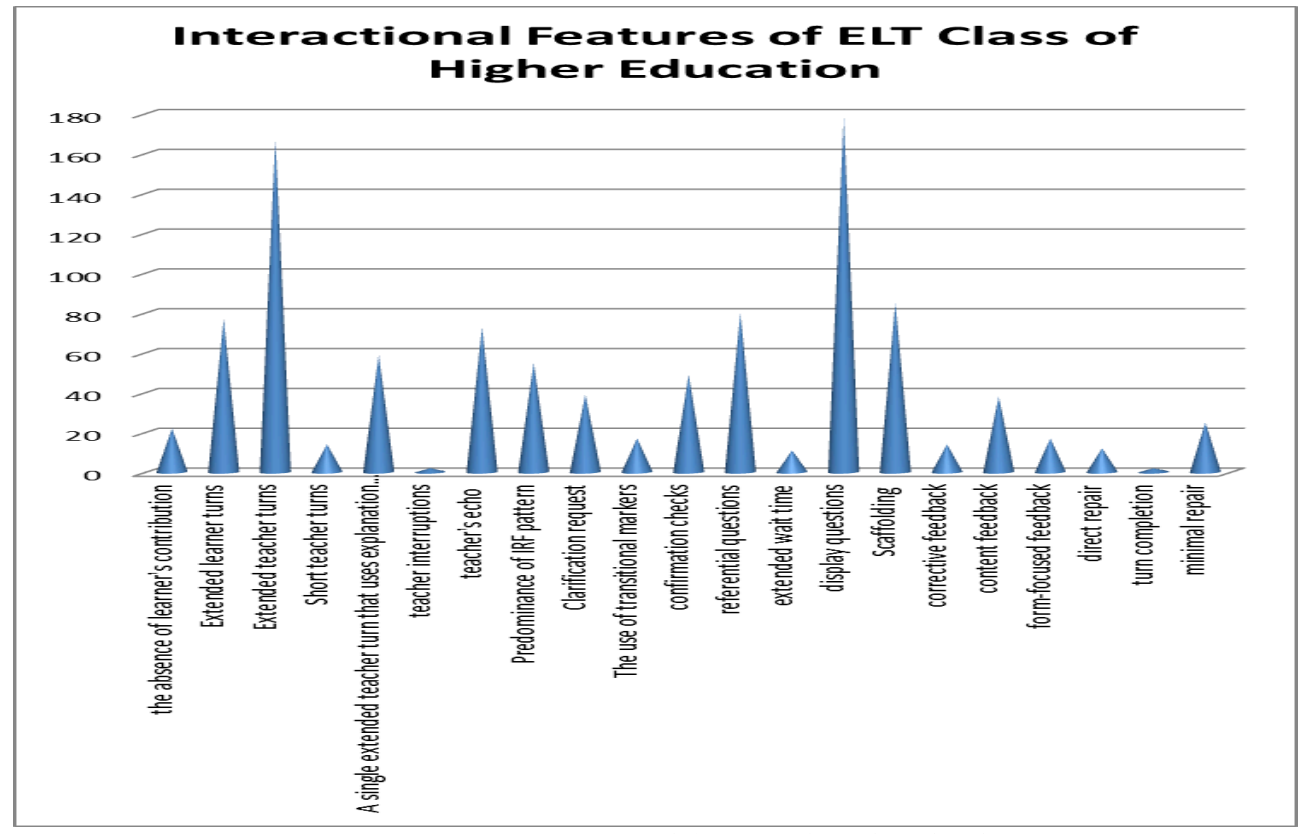

Figure 5. Interactional features found in the data

Summing up all of the data found, the mode mostly applied by the lecturers is managerial and material mode. It shows that the students still need assistance to comprehend the material discussed and to conduct the learning activity. These two modes are considered more urgent to be exposed rather than classroom context mode which focuses on the students fluency.

The condition is also reflected from the most interactional feature found, which is the extensive use of display questions and the extended teacher turn. The least interactional features found are teacher interruption and the extended wait-time. It shows that the lecturer will let the students contribution flows. They do not cut students participation unless it is necessary. Nevertheless, the lecturers do not allow students to think too long. When the students are facing difficulty, the lecturers will facilitate the interactional space by posing questions which can help contsructing the contribution or directly give explanation. It indicates the lecturers' sensitivity of classroom dynamics to facilitate the interactional space for the students. Although the interactional features found has more variety than what has been set in the framework, all of the interactional features are created to enable learners to speak more. It can be said that the interactional features are convergent to the pedagogic goals and the students level of English. 


\section{DISCUSSION}

Basically the expected ability of students majoring English in higher education is the competence of expressing critical thinking in English mastery. However, it can't be achieved easily due to limited contributions of the students. It can be related to the confidence to channel their thoughts in English because of language barrier. In such situation, the lecturers need to be able to bridge students limited interactional competence with the learning target. This is the condition where teacher need to adjust the modes, pedagogic goals, or the interactional features.

In order to elevate the students competence in English interaction, the mode mostly focused is material and managerial mode, instead of skills and system or classroom context mode which focus on language and fluency. It shows that the lecturers still need to enrich the students' knowledge around the material while managing the activity to support classroom context mode, where students are expected to express their critical thinking and shows the fluency of their English in the interaction. The lecturers expect the language used in cognitive activity will create language development [13]. Also, It shows the typical feature of English as a foreign language (EFL) that in EFL class the rights of speaking in the class is asymmetrical because teacher/lecturers control the activity, the goal and the interaction [12]. It is inevitable because when the students are not ready yet to express themselves, the lecturers need to prepare the readiness by creating such interactional features which students can respond to. Thus, the classroom interaction is created to make the students understand the discussion and interact in the because managerial and material mode support classroom context mode to perform the language mastery. Sometimes, the lecturers controlling the interaction is actually needed to achieve the learning objectives.

However, the focus of microcontext still needs to be matched so that the students have more independence in interaction and balanced participation in meaning negotiation for various learning activity. That the findings in pedagogical goal in skills and system mode are not as many as other modes shows that the lecturers have more focus on the fluency than accuracy. The situation indicates that the lecturers have not maximized the language mastery to make the students interact better because the mode to create better language focus is in the skills and system. When students have problems with the language, they will not be able to express themselves clearly.

The implication of this situation is that the students have not been able to use English confidently and interact in short way with the help of the lecturers. It reflects the typical feature of foreign language lecturers who spend most of the time organizing explanation or teaching, giving exercise or modifying questions so that the students do not have enough opportunity to evaluate or produce the language learned creatively [14]. Thus, the lecturers also need to improve the variety of modification related to the characteristics of assignment and students' competence to provide more assistance for the students' interactional competence. Despite the microcontext of skills and system need to be maximized, all the modes applied lead students to the better interaction. The lecturers use real communication to elevate their students' interactional competence. In other words, the language used in the class is convergent to the pedagogic goals to facilitate the interaction. It can be said that the lecturers facilitate interactional space for the students through the pedagogic goals. The interactional features which are mostly found in the class are extensive use of display questions and the extended teacher turn 
show that the lecturers use more positive effect feature to encourage repair of students' utterance [15]. It optimizes learning chance of the students because the lecturers can increase constructive effect feature and reduce destructive effect feature. Thus, it facilitates the interactional space. The implication of the situation is that the learning has been created to make the students interact in English better. Thus, all pedagogical activity in the class run through interaction and the success of a pedagogical activity needs a good classroom interaction.

\section{CONCLUSION}

Based on the research result, the findings, and discussion, it can be concluded that to bridge the expected learning objective and the student's ability, the lecturers can modify the interactional features in microcontexts and pedagogic goals. The lecturers can use the microcontext to scaffold the students contribution in English class. The variety of interactional features found shows that the lecturers has the competence and willingness to mediate and assist the learning. The interactional features reflect the way the lecturers use the language which is appropriate to the learners so that in the end they can still achieve the expected quality. Facilitating the language in interactional features can elevate the interactional competence of the students so that they are able to express their critical thinking fluently.

As the academic implication, it is confirmed that the interaction is directed by the lecturers through the pedagogic goals and interactional features as stated by Walsh. In EFL class, not all students are have the drive to get involve in the interaction due to the language ability. Thus, the flexibility of classroom interactional competence should be created so that the students can have better contribution. Thus, as the practical implications, the lecturers need to be able to modify the questioning in order that the students can increase the interactional competence. The lecturers need to always elaborate the students' response in order to generate more language contribution. Applying various interactional features will prepare the students to express themselves in English critically.

\section{REFERENCES}

[1] Badan Standar Nasional Pendidikan. 2010. Paradigma Pendidikan Nasional Abad XXI. Badan Standar Nasional Pendidikan. http://download.isi-dps.ac.id/index.php/.../5-peraturan-lainnya?abad21.

[2] Ramsden, Paul. 2003. Learning to Teach in Higher Education. London: Routledge.

[3] Walsh, Steve. 2011. Exploring Classroom Discourse: Language in Action. London: Routledge.

[4] kelahouse, Paul and Christopher Jenks. 2015 "Applying Global Perspective on ELT Classroom Interaction to current Issues in Language teaching" in International Perspectives on ELT Classroom Interaction. Paul Seedhouse and Christopher Jenks, eds. New York: Palgrave Macmillan

[5] McCharty, Michael and Steve Walsh 2003. "Discourse" in Practical English Language Teaching David Nunan, ed. Boston: McGraw Hill.

[6] Renandya, Willy A. and Handoyo Puji Widodo. 2016. "English Language Teaching Today: An Introduction" in English Language Teaching Today: Linking Theory and Practice. Willy A. Renandya and Handoyo Puji Widodo, eds. Singapore: Springer.

[7] Walsh, Steve. 2011. Investigating Classroom Discourse. London: Routledge.

[8] Kelantari, Reza. 2009. "Techniques for Classroom Interaction” in International Journal of Language Studies (IJLS), 3(4): 425-434. http://www.ijls.net/volumes/volume3issue4/kalantari1.pdf

[9] Hyland, Ken. 2009. Academic Discourse: English in Global Context. London: Continuum. 
[10] Mayuni, Ilza . 2007. Peningkatan Mutu Guru Bahasa Inggris melalui Pendidikan dalam Jabatan. Bandung: Lubuk Agung.

[11] Yu, Weihua. 2010. "An Analysis of College English Classroom Discourse" in Journal of Language Teaching and Research. 1(2): 136-144, http://www.academypublication.com/ issues/past/j1tr/vol01/02/07.pdf

[12] Cazden, Courtney B. and Sarah W. Beck. 2008. "Classroom Discourse" in Handbook of Discourse Process. Arthur C. Graesser et al., eds, New Jersey: Lawrence Earlbaum Associate Publishers.

[13] Behnam, Biook and Yassamin Pouriran. 2009. "Classroom Discourse: Analysing teacher/Learner Interactions in Iranian EFL Task-Based Classrooms" in International Porta Linguarium, http://www.ugr.es/ portalin/articulos/PL_numero12/8\%20Biook\%20Behnam.pdf

[14] Wang Li and Fang Huan. 2011 "A Self-evaluation of Classroom language Used When teaching Grammar” in International Education Studies. 4 (4) : 170-174. Doi: 10.5539/ies.v4n4p170,

[15] Shamsipour, Anahita and Hamid Allami. 2012. "Teacher talk and Learner Involvement in EFL Classroom: The case of Iranian Setting" in Theory and Practice in Language Studies. 2 (11): 22622268. Doi: 10.4304/tpls.2.11.2262-2268. 